\title{
The complex interplay among atherosclerosis, inflammation, and degeneration in ascending thoracic aortic aneurysms
}

Ornella Leone, MD, ${ }^{\mathrm{a}}$ Anna Corsini, MD, ${ }^{\mathrm{b}}$ Davide Pacini, MD, ${ }^{\mathrm{c}}$ Barbara Corti, MD, ${ }^{\mathrm{a}}$

Massimiliano Lorenzini, MD, ${ }^{\mathrm{d}}$ Vera Laus, MD, ${ }^{\mathrm{b}}$ Alberto Foà, MD, ${ }^{\mathrm{b}}$ Maria Letizia Bacchi Reggiani, MStat, ${ }^{\mathrm{b}}$

Luca Di Marco, MD, ${ }^{\mathrm{c}}$ and Claudio Rapezzi, $\mathrm{MD}^{\mathrm{b}}$

\section{ABSTRACT}

Objective: To assess the histopathological findings of a large series of ascending thoracic aortic aneurysm (TAA) surgical specimens applying the updated classification on noninflammatory degenerative and inflammatory aortic diseases proposed by the Association for European Cardiovascular Pathology and the Society for Cardiovascular Pathology clinicopathological correlations.

Methods: A total of 255 patients surgically treated for ascending TAA were enrolled. Surgical ascending aorta specimens were examined.

Results: The histopathological substrate of ascending TAAs was mainly degenerative $(67.5 \%)$, but with a remarkable prevalence of atherosclerotic lesions $(18.8 \%)$ and aortitis $(13.7 \%)$. Degenerative patients more frequently had bicuspid aortic valve $(37.2 \% ; P=.002)$. Patients in the atherosclerotic group were older (median age, 69 years; $P<.001$ ), more often with a history of hypertension $(87.5 \% ; P=.059)$, hypercholesterolemia $(75 \% ; P=.019)$, diabetes $(16.6 \% ; P=.054)$, current smoking $(22.9 \% ; P=.066)$, and a history of coronary artery disease $(18.7 \% ; P=.063)$. Patients with aortitis represented the older group (median age, 75 years, $P<.001$ ), were mostly females $(68.6 \%$; $P<.001$ ), and had a larger ascending aorta diameter (median, $56 \mathrm{~mm}$; $P<.001)$. Both patients with atherosclerosis and aortitis presented a higher incidence of concomitant abdominal aortic aneurysm $(20.8 \%$ and $22.8 \%$, respectively; $P<.001)$.

Conclusions: Although degenerative histopathology is the most frequent substrate in ascending TAA, atherosclerosis and inflammation significantly contribute to the development of chronic aortic thoracic disease. (J Thorac Cardi-

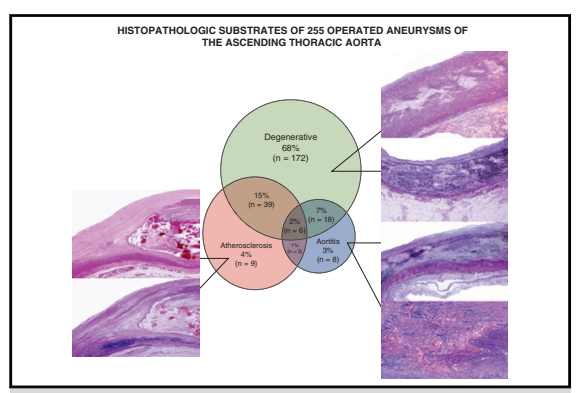

Histopathologic substrates of 255 operated aneurysms of the ascending thoracic aorta.

\section{Central Message}

Degenerative histopathology is the most frequent substrate in ascending thoracic aortic aneurysms, but atherosclerosis and inflammation contribute significantly to the development of chronic aortic thoracic disease.

\section{Perspective}

Awareness of the significant burden of aortitis and atherosclerosis-related inflammation might guide future research and therapies in the field of ascending thoracic aortic aneurysms.

See Commentary on page 1444. ovasc Surg 2020;160:1434-43)

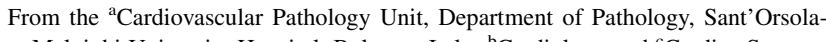
Malpighi University Hospital, Bologna, Italy; ${ }^{\mathrm{b}}$ Cardiology and ${ }^{\mathrm{c}}$ Cardiac Surgery, Department of Experimental Diagnostic and Specialty Medicine, Alma Mater Studiorum, University of Bologna, Bologna, Italy; and ${ }^{\mathrm{d}}$ University College London Institute for Cardiovascular Science and Barts Heart Centre, St. Bartholomew's Hospital, London, United Kingdom.

This study was partially funded by the Fanti Melloni Foundation, University of Bologna.

Received for publication March 12, 2019; revisions received Aug 11, 2019; accepted for publication Aug 26, 2019; available ahead of print Oct 1, 2019.

Address for reprints: Claudio Rapezzi, MD, Cardiology, Department of Experimental Diagnostic and Specialty Medicine, Alma Mater Studiorum, University of Bologna, Via G. Massarenti 9, 40138 Bologna, Italy (E-mail: claudio.rapezzi@ unibo.it).

0022-5223

Copyright $(2019$ by The American Association for Thoracic Surgery. Published by Elsevier Inc. This is an open access article under the CC BY-NC-ND license (http:// creativecommons.org/licenses/by-nc-nd/4.0/).

https://doi.org/10.1016/j.jtcvs.2019.08.108
From a clinical standpoint, thoracic aortic diseases mainly include thoracic aortic aneurysm (TAA) and type A acute aortic syndromes (AAS), which include aortic dissection, intramural hematoma, and penetrating aortic ulcer. Previous histopathological studies in chronic thoracic aortic diseases have focused mainly on the role of degenerative lesions of the medial aortic layer, first identified by Erdheim in 1930 as "aortic idiopathic (cystic) medial necrosis," ${ }^{1}$ leading to

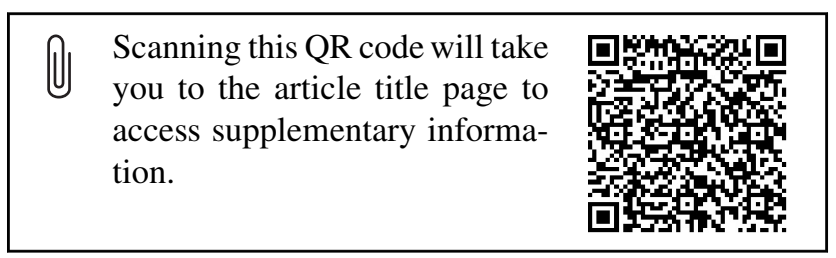




\section{Abbreviations and Acronyms \\ AAS = acute aortic syndrome \\ $\mathrm{AECVP}=$ Association for European \\ Cardiovascular Pathology \\ AHA $=$ American Heart Association \\ BAV = bicuspid aortic valve \\ CAD $=$ coronary artery disease \\ EFFL = elastic fiber fragmentation/loss \\ EFTO = elastic fiber thinning out \\ ICI = intralamellar collagen increase \\ I-MEMA $=$ intralamellar mucoid extracellular matrix accumulation \\ LMC = laminar medial collapse \\ MD = medial degeneration \\ SCVP = Society for Cardiovascular Pathology \\ TAA $=$ thoracic aortic aneurysm \\ TCI $=$ translamellar collagen increase \\ T-MEMA $=$ translamellar mucoid extracellular matrix accumulation}

the common perception of TAA as a mainly genetic-based disease associated with degenerative substrate. This conception may be challenged by recent histopathological advances, however. In particular, the Association for European Cardiovascular Pathology (AECVP) and the Society for Cardiovascular Pathology (SCVP) have proposed a revised and updated classification of the histopathologic diagnostic criteria for aortic diseases in 2 consensus statements on noninflammatory-degenerative ${ }^{2}$ and inflammatory ${ }^{3}$ aortic diseases. These criteria have not been applied to a large ascending TAA series to date.

In the present study, we assessed the histopathological findings of a large series of ascending TAA surgical specimens and searched for clinicopathological correlations.

\section{METHODS}

\section{Clinical Setting and Study Design}

The study population consisted of 255 patients who underwent surgery for ascending TAA at our center between January 1, 2015, and December 31,2016 . Patients age $<18$ years were excluded. We compared histopathological profiles of patients with chronic ascending TAA with those of patients with a final diagnosis of spontaneous type A acute aortic syndrome (AAS) treated surgically at our center between January 1, 2000, and December 31, 2013, whose data have been previously reported by our group. ${ }^{4}$ The study conforms to the principles outlined in the Declaration of Helsinki and was approved by our institutional Ethics Committee.

\section{Clinical Definitions}

The study population's main characteristics and clinical features at presentation were evaluated. Cardiovascular risk factors included a history of hypertension and ongoing antihypertensive therapy, hypercholesterolemia (total cholesterol $>200 \mathrm{mg} / \mathrm{dL}$ ) and ongoing lipid-lowering therapy, diabetes (type 1 or type 2), current smoking, familial history of premature coronary artery disease (CAD; ie, history of myocardial infarction affecting a first-degree relative younger than 55 years if men and 65 years if women). Known TAA in patients operated on for ascending TAA was defined as the presence of aneurysm in another thoracic vascular segment. Baseline glomerular filtration rate was calculated using the modified Modification of Diet in Renal Disease Study equation. ${ }^{5}$

\section{Histopathology}

Ascending aorta specimens ranging in length from 2.5 to $4.5 \mathrm{~cm}$ were examined for patients undergoing surgery for ascending TAA. An average of 6 samples were taken from each formalin-fixed specimen, processed routinely, and embedded in paraffin. The histologic sections were stained with standard hematoxylin and eosin and histomorphological staining for collagen (Azan-Mallory trichrome) and elastic fibers (Weigert-Van Gieson staining).

Histological samples were all evaluated de novo according to the diagnostic criteria from the 2 AECVP/SCVP documents ${ }^{2,3}$ by personnel blinded to the clinical data. Specifically, 2 categories of abnormalities were evaluated: noninflammatory/degenerative substrates and inflammatory substrates.

Noninflammatory/degenerative substrates. Overall degeneration of the aortic media was assessed as the sum of 6 major individual lesions involving various cellular and extracellular components of the medial layer:

- Mucoid extracellular matrix accumulation, an increase of mucopolysaccharides, both intralamellar (I-MEMA), preserving the arrangement of lamellar unit, and translamellar (T-MEMA), altering the structural architecture of the tunica media due to large pool formation

- Elastic fiber fragmentation/loss (EFFL)

- Elastic fiber thinning out (EFTO)

- Laminar medial collapse (LMC), a thin/dense band-like smooth muscle cell loss generating architectural compaction of elastic fibers

- Collagen increase, intralamellar (ICI), in the absence of significant alterations of the lamellar unit, and translamellar (TCI; ie, replacement fibrosis).

Overall medial degeneration (MD) was graded as mild, moderate, or severe, based on severity and distribution of each individual abnormality.

\section{Inflammatory substrates.}

- Atherosclerosis. After assessing single atherosclerotic plaques using the American Heart Association (AHA) schemes, ${ }^{6,7}$ atherosclerosis was classified and graded as not significant, mild, moderate, or severe using the simplified AECVP/SCVP classification, according to which only moderate or severe disease leads to significant medial damage

- Atherosclerosis with excessive inflammation (ie, with intense inflammatory reaction)

- Inflammatory atherosclerotic aneurysm

- Aortitis and periaortitis, classified according to histopathological inflammatory patterns (granulomatous/giant cells, lymphoplasmacytic, mixed inflammatory, and suppurative).

Only patients with moderate to severe atherosclerotic disease (AHA plaques V-VII) were classed as atherosclerotic.

\section{Clinicopathological Correlations}

To investigate clinicopathological correlations, the patients were classified according to 3 histopathological patterns: isolated degeneration (pure degenerative lesions or associated with mild atherosclerosis, ie AHA plaques I-IV), mainly atherosclerosis in the presence of moderate to severe atherosclerosis (isolated or associated with various degrees of degeneration), and aortitis (isolated or associated with various degrees of MD or atherosclerosis). 


\section{Statistical Analysis}

Categorical variables are expressed as number and percentage. Continuous variables are expressed as mean \pm standard deviation or median and interquartile range for normal or non-normal distribution, respectively.

Comparisons between categorical variables were performed with the $\chi^{2}$ test. Comparisons between 2 continuous variables were performed with the Student $t$ test or Wilcoxon test as appropriate. Comparisons among 3 groups were performed with analysis of variance (ANOVA) for height values and the Kruskal-Wallis test when the assumptions for ANOVA application were not met (ie, age, body mass index, glomerular filtration rate, systolic and diastolic blood pressure values, and ascending aorta diameters).

Variables with $P<.1$ in the univariate analysis were included in the multivariable analysis (multinomial logit model). All statistical analyses were performed using STATA/SE 14.2 (StataCorp, College Station, Tex).

\section{RESULTS}

\section{Clinical Findings in Patients With Ascending TAA}

Severe aortic stenosis was present in 26 of the 255 patients; severe aortic regurgitation in 77 patients, and concomitant severe stenosis and regurgitation in 4 patients. Concomitant aortic valve replacement was performed in 196 of the 255 patients.

Indications for surgery were as follows: maximal ascending aorta diameter $\geq 55 \mathrm{~mm}$ in 117 patients, maximal ascending aorta diameter $\geq 50 \mathrm{~mm}$ in the presence of a bicuspid aortic valve with additional risk factors in 29 patients, maximal ascending aorta diameter $\geq 45 \mathrm{~mm}$ in the presence of Marfan syndrome in 5 patients and LoeysDietz syndrome in 1 patient, and severe aortic stenosis or regurgitation with maximal ascending aorta diameter $\geq 45 \mathrm{~mm}$ in 103 patients. Table 1 reports the baseline characteristics and clinical features of the 255 patients with ascending TAA.

The median patient age was 66 years. A history of hypertension and antihypertensive therapy was common $(\mathrm{n}=211 ; 82.7 \%)$, as were hypercholesterolemia ( $\mathrm{n}=134 ; 52.5 \%)$ and receipt of lipid-lowering therapy $(\mathrm{n}=81 ; 31.7 \%)$. A higher percentage of patients were ex-smokers compared with current smokers $(32.9 \%$ $[\mathrm{n}=84]$ vs $13.7 \%[\mathrm{n}=35])$.

Bicuspid aortic valve (BAV) was common in patients with ascending TAA $(\mathrm{n}=77 ; 30.1 \%)$, whereas Marfan syndrome was rare $(\mathrm{n}=5 ; 1.9 \%)$; patients with $\mathrm{BAV}$ were younger (58 years vs 69 years; $P<.001$ ), and a had a lower rate of hypertension $(74 \%[\mathrm{n}=57]$ vs $86.5 \%$ [n $=154]$; $P=.015)$ (Table E1). The incidence of concomitant abdominal aortic aneurysm was $10.5 \%(\mathrm{n}=27)$.

\section{Histopathological Findings in Patients With Ascending TAA}

Tables 2 and E2 and Figures 1 and 3 present histopathological findings. In approximately $75 \%$ of the patients with ascending TAA, histopathology revealed a single pattern
TABLE 1. Characteristics of the Study Population at Presentation $(\mathbf{N}=\mathbf{2 5 5})$

\begin{tabular}{|c|c|}
\hline Characteristic & Value \\
\hline Age, y, median (IQR) & $66(58-74)$ \\
\hline Male sex, n (\%) & $189(74.1)$ \\
\hline BMI, $\mathrm{kg} / \mathrm{m}^{2}$, median (IQR) & $26(24-28)$ \\
\hline Height, $\mathrm{cm}$, mean $\pm \mathrm{SD}$ & $171 \pm 10$ \\
\hline Hypertension history, n (\%) & $211(82.7)$ \\
\hline Antihypertensive therapy, $\mathrm{n}(\%)$ & $211(82.7)$ \\
\hline Hypercholesterolemia, n (\%)* & $134(52.5)$ \\
\hline Lipid-lowering therapy, n (\%) & $81(31.7)$ \\
\hline Diabetes, n (\%) & $21(8.2)$ \\
\hline Insulin-dependent diabetes, $\mathrm{n}(\%)$ & $16(6.2)$ \\
\hline Non-insulin-dependent diabetes, n (\%) & $5(1.9)$ \\
\hline Current smoker, n (\%) & $35(13.7)$ \\
\hline Ex-smoker, n (\%) & $84(32.9)$ \\
\hline Familial history of CAD, $\mathrm{n}(\%)$ & $48(18.8)$ \\
\hline Previous ACS/exertion-induced angina, $\mathrm{n}(\%)$ & $25(9.8)$ \\
\hline Previous PTCA or CABG, $\mathrm{n}(\%)$ & $29(11.3)$ \\
\hline PAOD, n $(\%)$ & $1(0.3)$ \\
\hline Previous stroke/TIA, n (\%) & $15(5.8)$ \\
\hline Clinical diagnosis of aortitis, $\mathrm{n}(\%)$ & $5(1.9)$ \\
\hline Aortic coarctation, $\mathrm{n}(\%)$ & $3(1.1)$ \\
\hline Bicuspid aortic valve, $\mathrm{n}(\%)$ & $77(30.1)$ \\
\hline Turner syndrome, n (\%) & $1(0.3)$ \\
\hline Marfan syndrome, $\mathrm{n}(\%) \dagger$ & $5(1.9)$ \\
\hline Loeys-Dietz syndrome, $\mathrm{n}(\%) \dagger$ & $1(0.3)$ \\
\hline Ehlers-Danlos syndrome, $\mathrm{n}(\%) \dagger$ & $0(0)$ \\
\hline Previous aortic surgery, $\mathrm{n}(\%)$ & $20(7.8)$ \\
\hline Previous AAS, n (\%) & $7(2.7)$ \\
\hline $\begin{array}{l}\text { Known thoracic aortic aneurysm (surgically treated } \\
\text { or not), } \mathrm{n}(\%) \ddagger\end{array}$ & $13(5.1)$ \\
\hline $\begin{array}{l}\text { Known abdominal aortic aneurysm (surgically } \\
\text { treated or not), } \mathrm{n}(\%)\end{array}$ & $27(10.5)$ \\
\hline Familial history of aortic disease, $\mathrm{n}(\%)$ & $15(5.8)$ \\
\hline GFR, $\mathrm{mL} / \mathrm{min} / 1.73 \mathrm{~m}^{2}$, median $(\mathrm{IQR})$ & $84(66-102)$ \\
\hline Systolic blood pressure (mm Hg), median (IQR) & $120(120-135)$ \\
\hline Diastolic blood pressure (mm Hg), median (IQR) & $80(70-80)$ \\
\hline $\begin{array}{l}\text { Maximum ascending aorta diameter }(\mathrm{mm}), \text { median } \\
\quad(\mathrm{IQR}) \S\end{array}$ & $51(47-55)$ \\
\hline
\end{tabular}

$I Q R$, Interquartile range; $B M I$, body mass index; $S D$, standard deviation; $C A D$, coronary artery disease; ACS, acute coronary syndrome; PTCA, percutaneous transluminal coronary angioplasty; $C A B G$, coronary artery bypass graft; $P A O D$, peripheral arterial occlusive disease; TIA, transient ischemic attack; $A A S$, acute aortic syndrome; GFR, glomerular filtration rate. ${ }^{*}$ When the total cholesterol value was $>200$ or when the patient received lipid-lowering therapy. $\dagger$ A systematic genotyping was not available, so the effective prevalence of the different genetic syndromes could have been underestimated in our study population. $\ddagger$ Aneurysm in a thoracic aortic segment other than ascending. §Data available for 253 of 255 patients. 
TABLE 2. Histopathological findings in the study population $(\mathbf{N}=\mathbf{2 5 5})$

\begin{tabular}{lc}
\hline \multicolumn{1}{c}{ Diagnostic group } & Value, $\mathbf{n}(\%)$ \\
\hline Inflammatory-atherosclerosis & $9(3.5)$ \\
Inflammatory-aortitis & $8(3.1)$ \\
Degenerative & $172(67.5)$ \\
Mixed: Degenerative-atherosclerosis & $39(15.2)$ \\
Mixed: Degenerative-aortitis & $18(7.1)$ \\
Mixed: Atherosclerosis-aortitis & $3(1.1)$ \\
Mixed: Degenerative-atherosclerosis-aortitis & $6(2.3)$ \\
\hline
\end{tabular}

(degenerative in $67.5 \%$ of cases, atherosclerosis in $3.5 \%$, and aortitis in $3.1 \%$ ), whereas in approximately $25 \%$, the pattern was mixed (degenerative-atherosclerosis in $15.2 \%$, degenerative-aortitis in $7.1 \%$, atherosclerosisaortitis in $1.1 \%$, and degenerative-atherosclerosis-aortitis in $2.3 \%$ )

When the patients with ascending TAA were classified according to the 3 main histopathological patterns, MD was present in $172(67.5 \%)$, mainly atherosclerosis in 48 $(18.8 \%)$, and aortitis in $35(13.7 \%)$.

MD was the most frequent histopathological substrate found in ascending TAA $(\mathrm{n}=235 ; 92.2 \%)$, with isolated $(\mathrm{n}=172 ; 67.5 \%)$ or mixed patterns $(\mathrm{n}=63 ; 24.6 \%)$ and was most frequently moderate $(\mathrm{n}=130 ; 50.9 \%)$. As to individual degenerative lesions, MEMA was the most frequent type $(\mathrm{n}=244 ; 95.6 \%)$, more T-MEMA $(\mathrm{n}=234 ; 91.7 \%)$ than I-MEMA $(\mathrm{n}=201 ; 78.8 \%)$, followed by EFFL $(\mathrm{n}=243 ; 95.2 \%)$, ICI $(\mathrm{n}=219 ; 85.8 \%)$, and $\mathrm{EFTO}(\mathrm{n}=201 ; 78.8 \%)$. TCI and LMC were relatively rare $(n=92[36 \%]$ and $n=68[26.6 \%]$, respectively), the latter being more frequently associated with atherosclerosis rather than with a degenerative substrate. In particular, LMC associated with atherosclerosis was represented by a thick compaction band bordering the medial side of the plaques (Figure 1). Mucoid extracellular matrix and elastic fiber lesions, as well as ICI, were more frequently moderate and multifocal.

Atherosclerosis was present in a significant number of patients $(\mathrm{n}=57 ; 22.3 \%)$, most prevalently as a mixed pattern (degenerative-atherosclerosis in 39 [15.2\%], atherosclerosis-aortitis in $3[1.1 \%]$, and degenerativeatherosclerosis-aortitis in $6[2.3 \%])$. Atherosclerosis was graded moderate in 29 patients $(10.9 \%)$ and severe in 29 patients $(11.3 \%)$. In 81 patients $(31.7 \%)$, atherosclerotic lesions were mild and associated with other histopathological patterns. Atherosclerosis with excessive inflammation and inflammatory atherosclerotic aneurysm were very rare, found in 1 patient with ascending TAA (Figure 1).

Aortitis was found in 35 patients $(13.7 \%)$, most prevalently with a granulomatous-giant cell pattern $(n=20$;
$7.8 \%)$, followed by lymphoplasmacytic $(\mathrm{n}=2 ; 0.7 \%)$. In $5.1 \%$ of cases (13 patients), the inflammatory process was in a chronic/healing phase, the aortitis pattern was difficult to classify, and aortitis was considered unclassified; the inflammatory cell types were described, as was the presence of necrosis and scarring (Figure 1). All aortic specimens with aortitis had severely damaged vessel walls.

Periaortitis was present in 28 of 35 cases of ascending TAA aortitis $(80 \%)$ and was also found in other 17 cases of ascending TAA, where the histopathological substrate was atherosclerotic or degenerative (Figure 1). The periaortic inflammatory infiltrate grading was more frequently moderate $(\mathrm{n}=26 ; 10.1 \%)$ than mild $(\mathrm{n}=10 ; 3.9 \%)$ or severe $(\mathrm{n}=9 ; 3.5 \%)$.

\section{Clinicopathological Correlations in Patients With Ascending TAA}

As shown in Table 3 and Figure 2, the clinicopathological correlations were assessed according to 3 main categories: isolated degeneration $(\mathrm{n}=172 ; 67.5 \%)$, mainly atherosclerosis $(\mathrm{n}=48 ; 18.8 \%)$ and aortitis $(35,13.7 \%)$. The patients with isolated degeneration more frequently had a bicuspid aortic valve. The patients in the mainly atherosclerosis group were older and more often had a history of hypertension, hypercholesterolemia, diabetes, current smoking, and $\mathrm{CAD}$, particularly compared with the isolated degeneration group. The aortitis group was the oldest group, had a female predominance, and had a high prevalence of classical cardiovascular risk factors, such as hypertension, hypercholesterolemia, and diabetes. Moreover, a larger ascending aorta was more prevalent in the atherosclerotic group and even more so in the aortitis group. The prevalence of concomitant abdominal aortic aneurysm was higher in the atherosclerosis and aortitis groups compared with the isolated degeneration group. After multivariable analysis, variables independently associated with atherosclerotic patterns were older age, higher BMI, hypercholesterolemia, smoking, and larger ascending aorta diameter, and variables independently associated with aortitis pattern were older age, female sex, higher BMI, and larger ascending aorta diameter (Table 4).

The distribution of histopathological lesions according to age in ascending TAA patients is reported in Table E3. Degenerative lesions were more frequent in patients age $\leq 65$ years $(\mathrm{n}=118 ; 46.3 \%)$ compared with those age $>65$ years $(\mathrm{n}=137 ; 53.7 \%)(\mathrm{n}=99[83.8 \%]$ vs $\mathrm{n}=73$ [53.2\%]; $P<.001)$ than. In contrast, older patients more frequently had mixed degenerative-atherosclerotic lesions were more common in the patients age $>65$ years $(\mathrm{n}=29$ $[21.1 \%]$ vs $\mathrm{n}=10[8.4 \%] ; P=.008)$. Overall MD grading was similar in the 2 age groups. As to individual degenerative lesions, the younger patients had more intralamellar MEMA, EFTO and ICI, whereas the older ones had more TCI. No between-group differences were found in EFFL 


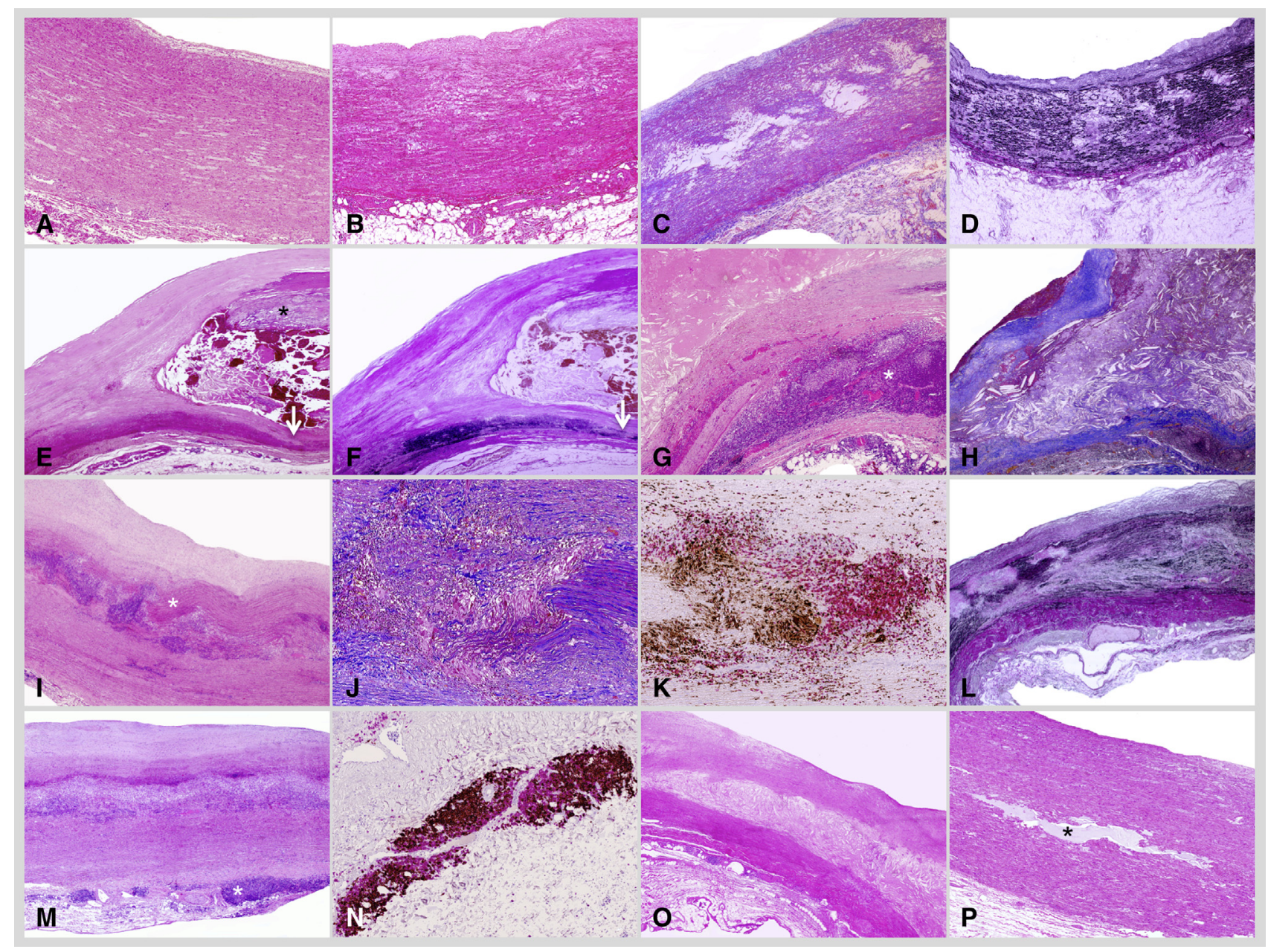

FIGURE 1. Main histopathologies of ascending thoracic aortic aneurysm. A-D, Degenerative aneurysm cases. A, Mild medial degeneration (MD) prevalently characterized by elastic fiber thinning out (EFTO) and intralamellar mucoid extracellular matrix accumulation (I-MEMA) (hematoxylin and eosin, $50 \times$ ). B, Moderate degenerative alterations with EFTO/elastic fiber fragmentation/loss (EFFL) and I-MEMA/translamellar mucoid extracellular matrix accumulation (T-MEMA) (hematoxylin and eosin, 50×). C and D, Severe MD with large areas of accumulated extracellular matrix (C, Azan-Mallory trichrome stain, 25×) and severe EFFL (D, Weigert-Van Gieson stain, 25×). E-H, Mainly atherosclerosis pattern. E and F, Advanced fibroatheroma with calcification (asterisk). The underlying medial layer is thinned and destroyed by replacement fibrosis (E, arrow; hematoxylin and eosin; $25 \times$ ); only residual elastic lamellas are evident (F, arrow; Weigert-Van Gieson stain; 25×). G and H, Inflamed atherosclerosis with plaque rupture. Under the plaque and in the periaortic tissue are extensive inflammatory infiltrates, partially with a follicular-like structure $(\mathrm{G}$, asterisk, hematoxylin and eosin, $25 \times$; $\mathrm{H}, \mathrm{Azan}-$ Mallory trichrome stain, $25 \times$ ). I-L, Giant cell aortitis, the most frequent type found. I, Severe and extensive inflammation in the medial layer and at the intimal-medial junction associated with areas of acellular laminar necrosis (asterisk, hematoxylin and eosin, 25×). J, Inflammatory infiltrates are composed of lymphocytes, macrophages, and giant cells with or without granulomas (Azan-Mallory trichrome stain, 50×). K, Double CD68/CD3 immunostaining highlights macrophages and giant cells (brown) and T lymphocytes (red) (original magnification 100×). L, Elastic fiber staining highlighting the severe, widespread alteration of the aortic wall due to the inflammatory disease (Weigert-Van Gieson stain, $25 \times$ ). M-P, A case of severe aortitis with granulomatous/ giant cell pattern and chronic periaortitis (M, asterisk, hematoxylin and eosin, $25 \times$ ). N, Double CD20/CD3 immunostaining showing that B lymphocytes (brown) prevail over T lymphocytes (red) (original magnification, 100×). O and P, Aneurysm with mixed atherosclerosis-degenerative pattern: fibroatheroma (American Heart Association grade V) (hematoxylin and eosin, 25×) and, in another area, extracellular matrix accumulation (T-MEMA) within an EFFL zone (hematoxylin and eosin, $25 \times$ ).

and translamellar MEMA. The grading of atherosclerosis was more frequently severe in the older patients $(n=24$ $[17.5 \%]$ vs $\mathrm{n}=5[4.2 \%] ; P=.001)$. Aortitis was more frequent in the older patients $(\mathrm{n}=29[21.1 \%]$ vs $\mathrm{n}=6$ $[5.1 \%] ; P<.001)$, with a pattern that was predominantly granulomatous-giant cell and healed.

\section{DISCUSSION}

Here we report the histopathological findings of a large series of patients with TAA using the recent and not yet widely validated AECVP and SCVP classification systems. ${ }^{2,3}$ This new system is receiving increasing attention for many reasons, including the standardization of 
BICUSPID AORTIC VALVE

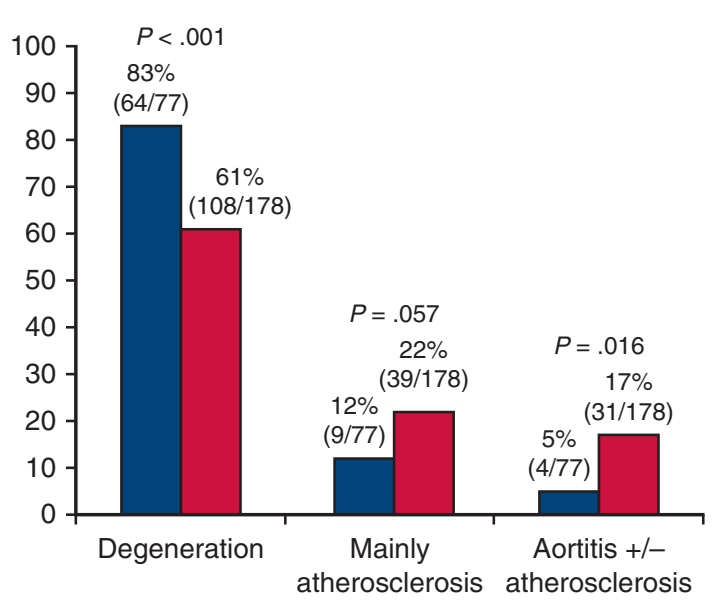

$\square$ bicuspid AV $\square$ trileaflet AV

\section{GENDER}

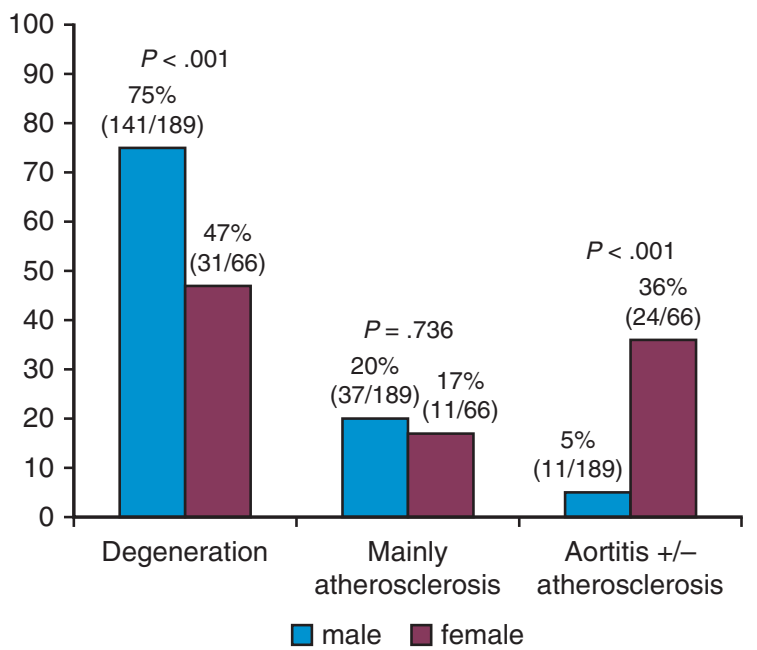

AGE

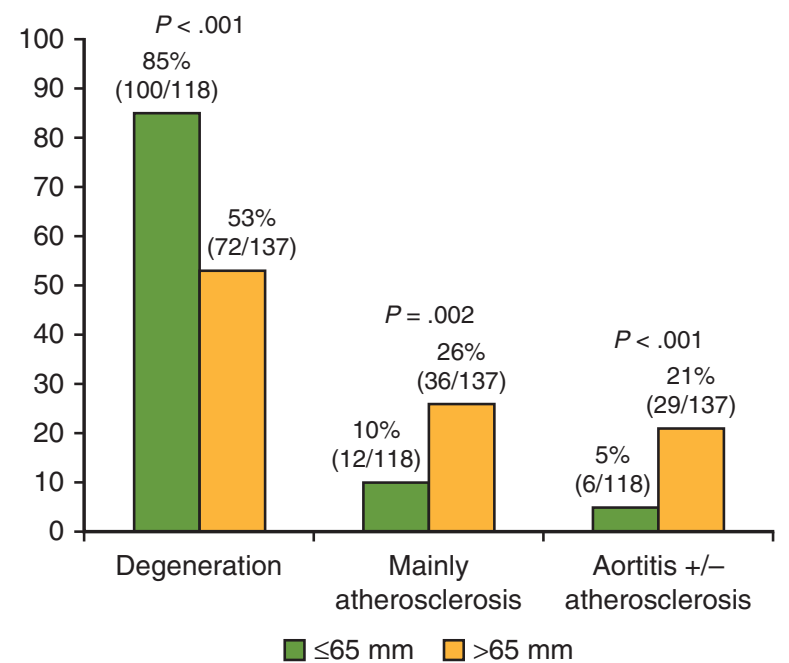

AORTIC DIAMETER

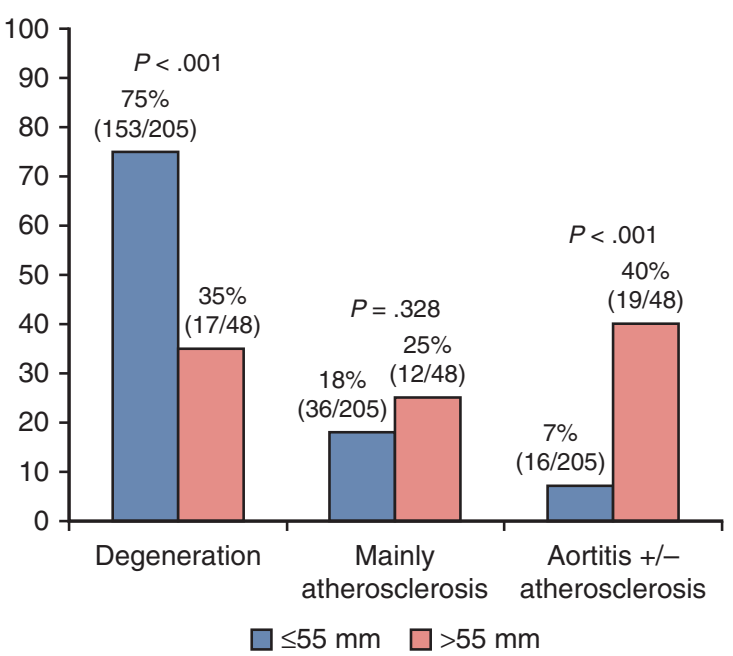

ASSOCIATED ABDOMINAL AORTIC ANEURYSM

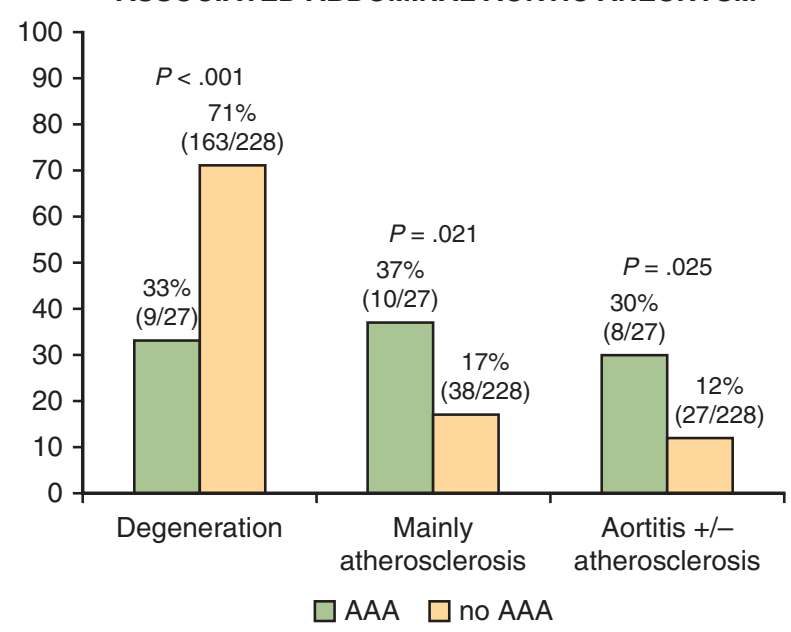

FIGURE 2. Histopathological findings according to predefined subgroups in patients with ascending thoracic aortic aneurysm. $A V$, Aortic valve; $A A A$, abdominal aortic aneurysm. 


\section{HISTOPATHOLOGIC SUBSTRATES OF 255 OPERATED ANEURYSMS OF THE ASCENDING THORACIC AORTA}

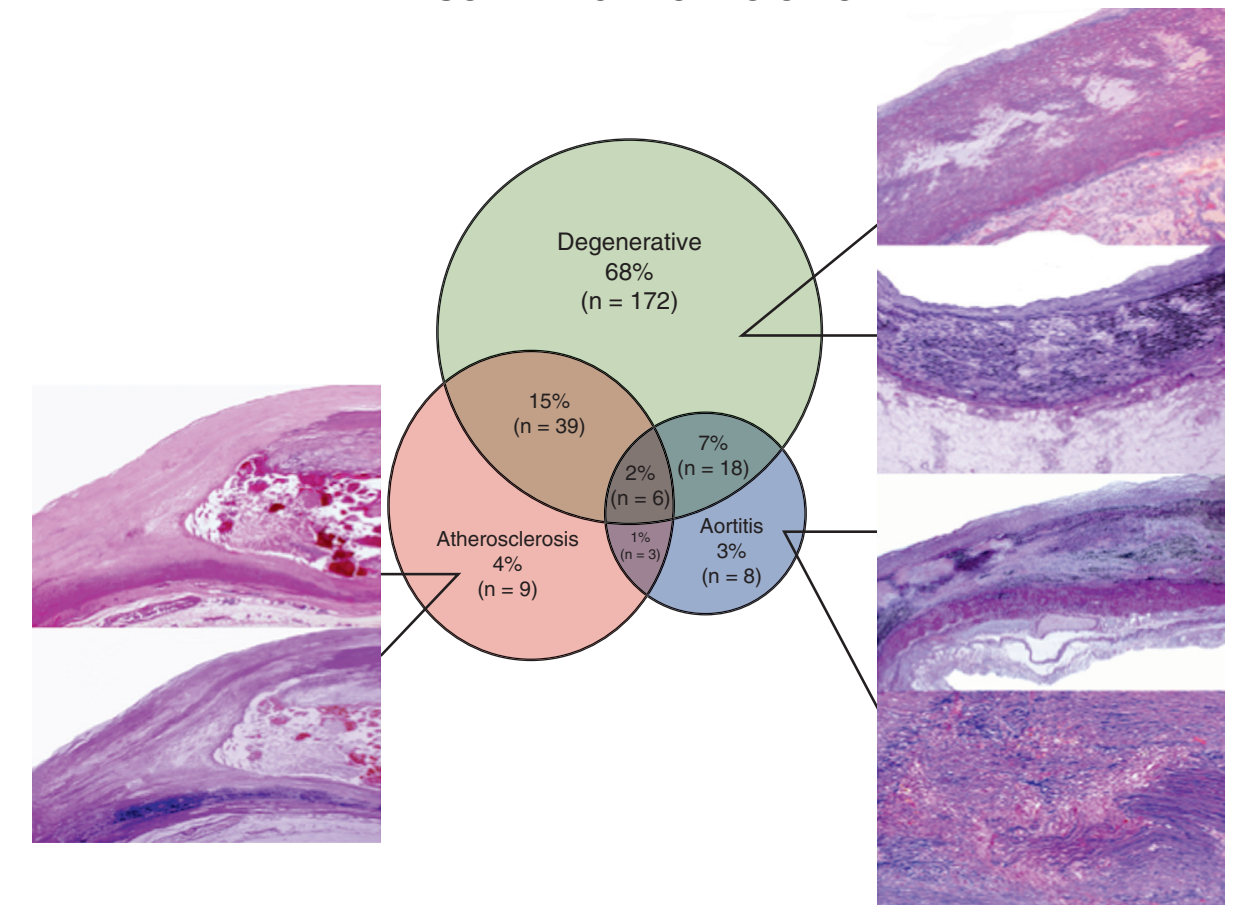

FIGURE 3. The spectrum of histopathological findings in patients with ascending thoracic aortic aneurysm.

nomenclature, a clear definition of diagnostic categories, and the standardization of histopathological diagnostic criteria for inflammatory and degenerative lesions, still a poorly defined topic. Our study documents the applicability and usefulness of such a system in the setting of ascending aorta lesions necessitating surgical therapy.

Although MD is confirmed as the most common finding in ascending TAA, ${ }^{8}$ atherosclerosis and aortitis are the main histopathological substrates in a significant number of cases (1 in 3). Across these main patterns, mixed forms (with 2 or more types of lesions) are quite common (approximately $25 \%)$.

Comparing the histopathological profile of patients with ascending TAA with that seen in a series of patients operated on for type A AAS previously described by our group, ${ }^{4}$ we see that acute and chronic forms have a similar prevalence of degenerative and atherosclerotic lesions (in AAS, isolated MD in $77.2 \%$ and mainly atherosclerosis in $22.8 \%$ ). In both ascending TAA and AAS, the coexistence of 2 or more patterns (mixed forms) is also quite common (approximately $25 \%$ ). Of note, the presence of LMC is not confined to the degenerative pattern but can also be associated with atherosclerosis and is likely the common final result of different pathogenetic mechanisms; LMC is much more frequent and extensive in the acute setting. Patients with AAS showed a higher prevalence of severe MD lesions compared with those with ascending TAA ( $24.1 \%$ vs $14.9 \%)$, and aortitis was found in $13.7 \%$ of ascending TAA cases but was not described in the AAS setting.

Our study also provides some interesting clinicopathological correlations by comparing clinical profiles across the 3 main histological patterns (Table 3) and considering 5 prespecified subgroups (Figure 2). Compared with degenerative patients, atherosclerotic patients with ascending TAA were older and more frequently had a history of hypertension, hypercholesterolemia, diabetes, current smoking, and a history of coronary artery disease. Patients with aortitis were older and mostly female, and had significantly larger ascending aortas. Similar correlations among sex, age, and histological substrate of aortic lesions have been reported by Nesi and colleagues ${ }^{8}$ in a cohort of 171 patients with surgically treated TAA. In patients with aortitis, the most common histopathological pattern was granulomatous-giant cell, as reported in other series. ${ }^{9,10}$ Approximately $40 \%$ of patients with aortitis showed a healing phase, with massive fibrosis likely protecting the wall from dissection. Chronic periaortitis was associated with $80 \%$ of cases and likely contributed to the overall remodeling process. In most cases, the diagnosis of aortitis had not been suspected before surgery. Aortic and periaortic inflammation can be investigated with noninvasive imaging 
TABLE 3. Clinicopathological correlations in patients with thoracic aortic aneurysm

\begin{tabular}{|c|c|c|c|c|}
\hline Characteristic & $\begin{array}{c}\text { Isolated } \\
\text { degeneration } \\
(\mathrm{N}=\mathbf{1 7 2 ;} \mathbf{6 7 . 5 \%})\end{array}$ & $\begin{array}{c}\text { Mainly } \\
\text { atherosclerosis } \\
(\mathrm{N}=\mathbf{4 8} ; \mathbf{1 8 . 8} \%)\end{array}$ & $\begin{array}{c}\text { Aortitis with/without } \\
\text { atherosclerosis } \\
(\mathrm{N}=35 ; 13.7 \%)\end{array}$ & $P$ value \\
\hline Age, y, median (IQR) & $63(53-70)$ & $69(66-75)$ & $75(71-78)$ & $<.001$ \\
\hline Male sex, n (\%) & $141(81.9)$ & $37(77.1)$ & $11(31.4)$ & $<.001$ \\
\hline BMI, kg/m², median (IQR) & $26(24-28)$ & $27(24-30)$ & $27(24-30)$ & .12 \\
\hline Height, $\mathrm{cm}$, mean $\pm \mathrm{SD}$ & $173 \pm 9$ & $171 \pm 10$ & $163 \pm 10$ & .808 \\
\hline Hypertension (history), n (\%) & $136(79.1)$ & $42(87.5)$ & $33(94.2)$ & .059 \\
\hline Antihypertensive therapy, $\mathrm{n}(\%)$ & 137 (79.6) & $41(85.4)$ & $33(94.2)$ & .097 \\
\hline Hypercholesterolemia, $\mathrm{n}(\%)^{*}$ & $90(52.3)$ & $36(75)$ & $20(57.1)$ & .019 \\
\hline Lipid-lowering therapy, n (\%) & $40(23.2)$ & $30(62.5)$ & $11(31.4)$ & $<.001$ \\
\hline Diabetes, n (\%) & $10(5.8)$ & $8(16.6)$ & $3(8.5)$ & .054 \\
\hline Insulin-dependent diabetes, $\mathrm{n}(\%)$ & $3(1.7)$ & $2(4.1)$ & $0(0)$ & .376 \\
\hline Non-insulin-dependent diabetes, $\mathrm{n}(\%)$ & $7(4)$ & $6(12.5)$ & $3(8.5)$ & .086 \\
\hline Current smoker, n (\%) & $22(12.7)$ & $11(22.9)$ & $2(5.7)$ & .066 \\
\hline Ex-smoker, n (\%) & $49(28.4)$ & $21(43.7)$ & $14(40)$ & .088 \\
\hline Familial history of CAD, $\mathrm{n}(\%)$ & $32(18.6)$ & $12(25)$ & $3(8.5)$ & .162 \\
\hline Previous ACS/exertion-induced angina, $\mathrm{n}(\%)$ & $14(8.1)$ & $9(18.7)$ & $2(5.7)$ & .063 \\
\hline Previous PTCA or CABG, n (\%) & $18(10.4)$ & $8(16.6)$ & $3(8.5)$ & .417 \\
\hline PAOD, n (\%) & $1(0.5)$ & $0(0)$ & $0(0)$ & .785 \\
\hline Previous stroke/TIA, n (\%) & $9(5.2)$ & $3(6.2)$ & $3(8.5)$ & .741 \\
\hline Clinical diagnosis of aortitis, $\mathrm{n}(\%)$ & $0(0)$ & $1(2.1)$ & $4(11.4)$ & $<.001$ \\
\hline Aortic coarctation, $\mathrm{n}(\%)$ & $3(1.7)$ & $0(0)$ & $0(0)$ & .481 \\
\hline Bicuspid aortic valve, $\mathrm{n}(\%)$ & $64(37.2)$ & $9(18.7)$ & $4(11.4)$ & .002 \\
\hline Turner syndrome, $\mathrm{n}(\%)$ & $1(0.5)$ & $0(0)$ & $0(0)$ & .785 \\
\hline Marfan syndrome, n (\%) & $5(2.9)$ & $0(0)$ & $0(0)$ & .292 \\
\hline Loeys-Dietz syndrome, n (\%) & $1(0.5)$ & $0(0)$ & $0(0)$ & .785 \\
\hline Ehlers-Danlos syndrome, n (\%) & $0(0)$ & $0(0)$ & $0(0)$ & NA \\
\hline Previous aortic surgery, n (\%) & $13(7.5)$ & $6(12.5)$ & $1(2.8)$ & .264 \\
\hline Previous AAS, n (\%) & $6(3.4)$ & $1(2.1)$ & $0(0)$ & .491 \\
\hline Known thoracic aortic aneurysm (surgically treated or not), $\mathrm{n}(\%) \dagger$ & $6(3.4)$ & $5(10.4)$ & $2(5.7)$ & .153 \\
\hline Known abdominal aortic aneurysm (surgically treated or not), $\mathrm{n}(\%)$ & $9(5.2)$ & $10(20.8)$ & $8(22.8)$ & $<.001$ \\
\hline Familial history of aortic disease, $\mathrm{n}(\%)$ & $11(6.3)$ & $3(6.2)$ & $0(0)$ & .308 \\
\hline GFR, $\mathrm{mL} / \mathrm{min} / 1.73 \mathrm{~m}^{2}$, median (IQR) & $88(73-103)$ & $79(64-94)$ & $66(55-88)$ & .471 \\
\hline Systolic blood pressure (mm Hg), median (IQR) & $120(120-130)$ & $120(120-140)$ & $120(120-140)$ & .219 \\
\hline Diastolic blood pressure (mm Hg), median (IQR) & $80(70-80)$ & $80(75-80)$ & $80(70-80)$ & .271 \\
\hline Maximum ascending aorta diameter $(\mathrm{mm})$, median (IQR) & $50(46-53) \ddagger$ & $52(50-58)$ & $56(51-62)$ & $<.001$ \\
\hline
\end{tabular}

$I Q R$, Interquartile range; $B M I$, body mass index; $S D$, standard deviation; $C A D$, coronary artery disease; $A C S$, acute coronary syndrome; $P T C A$, percutaneous transluminal coronary angioplasty; $C A B G$, coronary artery bypass graft; $P A O D$, peripheral arterial occlusive disease; $T I A$, transient ischemic attack; $N A$, not applicable; $A A S$, acute aortic syndrome; GFR, glomerular filtration rate. *When the total cholesterol value was $>200$ or when the patient received lipid-lowering therapy. †Aneurysm in a thoracic aortic segment other than ascending. $\ddagger$ Data available for 170 of 172 patients.

techniques, but the therapeutic implications remain to be been fully established. ${ }^{11}$

Patients with ascending TAA with atherosclerosis and aortitis frequently had a concomitant abdominal aortic aneurysm. The pathogenetic role of inflammation in aortic aneurysms has been addressed mainly in the context of abdominal aneurysms, ${ }^{12-17}$ whereas the implications of inflammatory substrates for thoracic aortic remodeling have yet to be fully established. ${ }^{12,18,19}$ Medial inflammatory response to atherosclerosis is known to correlate 
TABLE 4. Multivariable analysis for clinicopathological correlations in patients with thoracic aortic aneurysm

\begin{tabular}{|c|c|c|c|c|c|c|}
\hline Variable & $\begin{array}{c}\text { Mainly atherosclerosis } \\
\text { vs isolated degeneration, } \\
\text { OR }(95 \% \text { CI })\end{array}$ & $P$ value & $\begin{array}{l}\text { Aortitis with/without } \\
\text { atherosclerosis vs } \\
\text { isolated degeneration, } \\
\text { OR }(95 \% \text { CI })\end{array}$ & & $\begin{array}{c}\text { Mainly atherosclerosis } \\
\text { vs aortitis with/without } \\
\text { atherosclerosis, } \\
\text { OR }(95 \% \text { CI })\end{array}$ & $P$ value \\
\hline Age (for each 1-y increase) & $1.08(1.03-1.13)$ & .002 & $1.09(1.03-1.17)$ & .004 & $1.01(0.95-1.09)$ & .676 \\
\hline Male sex & $0.45(0.17-1.23)$ & .123 & $0.05(0.01-0.15)$ & $<.001$ & $0.11(0.04-0.34)$ & $<.001$ \\
\hline BMI (for each $1 \mathrm{~kg} / \mathrm{m}^{2}$ increase) & $1.11(1-1.23)$ & .034 & $1.15(1.01-1.3)$ & .03 & $1.03(0.91-1.17)$ & .64 \\
\hline Hypertension (history) & $0.61(0.16-2.24)$ & .461 & $2.83(0.42-18.94)$ & .282 & $4.61(0.62-34.5)$ & .136 \\
\hline Hypercholesterolemia* & $2.92(1.2-7.12)$ & .018 & $1.36(0.49-3.73)$ & .544 & $0.47(0.15-1.44)$ & .184 \\
\hline Diabetes & $2.35(0.75-7.32)$ & .139 & $1.31(0.24-7.16)$ & .75 & $0.56(0.1-0.05)$ & .502 \\
\hline Current smoker & $3.95(1.32-11.76)$ & .014 & $0.71(0.11-4.5)$ & .717 & $0.17(0.03-1.16)$ & .072 \\
\hline Ex-smoker & $3.18(1.32-7.62)$ & .009 & $2.23(0.74-6.69)$ & .151 & $0.7(0.22-2.23)$ & .55 \\
\hline $\begin{array}{l}\text { Previous ACS/exertion-induced } \\
\text { angina }\end{array}$ & $1.23(0.39-3.82)$ & .715 & $0.48(0.07-3.07)$ & .446 & $0.39(0.06-2.57)$ & .333 \\
\hline Bicuspid aortic valve & $0.94(0.35-2.49)$ & .904 & $0.66(0.16-2.73)$ & .576 & $0.71(0.15-3.31)$ & .664 \\
\hline $\begin{array}{l}\text { Known abdominal aortic aneurysm } \\
\text { (surgically treated or not) }\end{array}$ & $1.14(0.34-3.73)$ & .825 & $1.58(0.38-6.51)$ & .523 & $1.38(0.34-5.68)$ & .649 \\
\hline $\begin{array}{l}\text { Maximum ascending aorta diameter } \\
\text { (for each } 1-\mathrm{mm} \text { increase) }\end{array}$ & $1.08(1.03-1.14)$ & .001 & $1.08(1.02-1.15)$ & .005 & $0.99(0.95-1.04)$ & .895 \\
\hline
\end{tabular}

OR, Odds ratio; $C I$, confidence interval; BMI: body mass index; $A C S$ : acute coronary syndrome. "When the total cholesterol value was $>200$ or when the patient received lipidlowering therapy.

with a negative histological remodeling of the aortic media. $^{20}$

Overall, age was a strong determinant of the histopathological substrate, with a higher prevalence of atherosclerosis and aortitis in subjects age $>65$ years (Figure 2). Age also influences the type of degenerative lesion. Agerelated aortic changes include the loss of elastin content with elastic fiber fragmentation and loss and increase of other matrix components, primarily collagen. Fragmentation of elastic fibers creates gaps in the lamellar structure of the aorta, which are partially filled with proteoglycans (T-MEMA). In our cohort, younger patients were found to have I-MEMA and EFTO more frequently, whereas the prevalences of EFFL and T-MEMA were similar in the 2 age groups. Increased collagen was more frequently intralamellar in young patients and translamellar in older ones, where the scar-like morphology suggests a repair process.

It was difficult to assess the effect of genetics on the histological substrate in our cohort, due to the low prevalence of patients with genetic syndromes and the unavailability of systematic genotyping. Nonetheless, it is known that genetic syndromes lead to degenerative changes that are mainly mucoid, and that elastic fiber lesions are more extensive and occur at an earlier age. ${ }^{21} \mathrm{~A}$ recent study by Waters and colleagues ${ }^{22}$ that analyzed 148 surgical ascending aorta specimens (including both aneurysms and dissections) found that patients with
Marfan syndrome had more overall MD and MEMA compared with patients with other hereditary syndromes and those with nonsyndromic aortopathies. In our study population, the 5 patients with Marfan syndrome were younger (mean age, 37 years) with a purely degenerative substrate and overall moderate MD in 3 cases and severe MD in 2 cases.

BAV was associated with MD lesions in approximately $83 \%$ of cases. BAV was frequent in patients with ascending TAA and relatively rare in our previously described series of AAS, but this is at least partially due to our center's policy of prophylactic surgery in patients with BAV and aortic dilatation.

This study has several limitations. We analyzed a singlecenter cohort with a limited number of patients and without systematic genetic assessment. The possible prognostic implications of histological findings in this setting were not assessed. The exclusion of patients age $<18$ necessarily restricted the spectrum of histopathological findings and the contribution of genetic-based mechanisms.

\section{CONCLUSIONS}

Although degenerative histopathology is the most frequent substrate in ascending TAA, atherosclerosis and inflammation significantly contribute to the development of chronic aortic thoracic disease, either in isolation or in mixed patterns. Awareness of the significant burden of aortitis and atherosclerosis-related inflammation could 
potentially guide future research and the development of innovative therapies in this field.

\section{Conflict of Interest Statement}

Dr Lorenzini: Pfizer. All other authors have nothing to disclose with regard to commercial support.

\section{References}

1. Erdheim J. Medionecrosis aortae idiopathica cystica. Virchows Arch Pathol Anat Physiol Klin Med. 1930;276:187-229.

2. Halushka MK, Angelini A, Bartoloni G, Basso C, Batoroeva L, Bruneval P, et al. Consensus statement on surgical pathology of the aorta from the Society for Cardiovascular Pathology and the Association for European Cardiovascular Pathology, II: noninflammatory degenerative diseases-nomenclature and diagnostic criteria. Cardiovasc Pathol. 2016;25:247-57.

3. Stone JR, Bruneval P, Angelini A, Bartoloni G, Basso C, Batoroeva L, et al. Consensus statement on surgical pathology of the aorta from the Society for Cardiovascular Pathology and the Association for European Cardiovascular Pathology, I: Inflammatory diseases. Cardiovasc Pathol. 2015; 24:267-78.

4. Leone O, Pacini D, Foà A, Corsini A, Agostini V, Corti B, et al. Redefining the histopathologic profile of acute aortic syndromes: clinical and prognostic implications. J Thorac Cardiovasc Surg. 2018;156:1776-85.e6.

5. Levey AS, Bosch JP, Lewis JB, Greene T, Rogers N, Roth D. A more accurate method to estimate glomerular filtration rate from serum creatinine: a new prediction equation. Modification of diet in renal disease study group. Ann Intern Med. 1999;130:461-70.

6. Stary HC, Chandler AB, Glagov S, Guyton JR, Insull W Jr, Rosenfeld ME, et al. A definition of initial, fatty streak, and intermediate lesions of atherosclerosis. A report from the Committee on Vascular Lesions of the Council on Atherosclerosis, American Heart Association. Arterioscler Thromb Vasc Biol. 1994;14: 840-56.

7. Stary HC, Chandler AB, Dinsmore RE, Fuster V, Glagov S, Insull W Jr, et al. A definition of advanced types of atherosclerotic lesions and a histological classification of atherosclerosis. A report from the Committee on Vascular Lesions of the Council on Atherosclerosis, American Heart Association. Arterioscler Thromb Vasc Biol. 1995;15:1512-31.

8. Nesi G, Anichini C, Tozzini S, Boddi V, Calamai G, Gori F. Pathology of the thoracic aorta: a morphologic review of 338 surgical specimens over a 7-year period. Cardiovasc Pathol. 2009;18:134-9.
9. Pacini D, Leone O, Turci S, Camurri N, Giunchi F, Martinelli GN, et al. Incidence, etiology, histologic findings, and course of thoracic inflammatory aortopathies. Ann Thorac Surg. 2008;86:1518-23.

10. Homme JL, Aubry MC, Edwards WD, Bagniewski SM, Shane Pankratz V, Kral CA, et al. Surgical pathology of the ascending aorta: a clinicopathologic study of 513 cases. Am J Surg Pathol. 2006;30:1159-68.

11. Taglieri N, Nanni C, Ghetti G, Bonfiglioli R, Saia F, Bacchi Reggiani ML, et al. Relation between thoracic aortic inflammation and features of plaque vulnerability in the coronary tree in patients with non-ST segment elevation acute coronary syndrome undergoing percutaneous coronary intervention. An FDGpositron emission tomography and optical coherence tomography study. Eur J Nucl Med Mol Imaging. 2017;44:1878-87.

12. Guo DC, Papke CL, He R, Milewicz DM. Pathogenesis of thoracic and abdominal aortic aneurysms. Ann N Y Acad Sci. 2006;1085:339-52.

13. Beckman EN. Plasma cell infiltrates in atherosclerotic abdominal aortic aneurysms. Am J Clin Pathol. 1986;85:21-4.

14. Lindholt JS, Shi GP. Chronic inflammation, immune response, and infection in abdominal aortic aneurysms. Eur J Vasc Endovasc Surg. 2006;31: 453-63.

15. Rasmussen TE, Hallett JW Jr. Inflammatory aortic aneurysms. A clinical review with new perspectives in pathogenesis. Ann Surg. 1997;225:155-64.

16. Hirose H, Tilson MD. Abdominal aortic aneurysm as an autoimmune disease. Ann N Y Acad Sci. 2001;947:416-8.

17. Vaglio A, Buzio C. Chronic periaortitis: a spectrum of diseases. Curr Opin Rheumatol. 2005;17:34-40.

18. Yoshida M, Mukohara N, Honda T, Ozaki N, Shida T. Inflammatory aneurysm of the ascending aorta: report of a case. Surg Today. 2007;37:794-7.

19. He R, Guo DC, Estrera AL, Safi HJ, Huynh TT, Yin Z, et al. Characterization of the inflammatory and apoptotic cells in the aortas of patients with ascending thoracic aortic aneurysms and dissections. J Thorac Cardiovasc Surg. 2006; 131:671-8.

20. van der Wal AC, Becker AE, Das PK. Medial thinning and atherosclerosis-evidence for involvement of a local inflammatory effect. Atherosclerosis. 1993;103: 55-64.

21. Maleszewski JJ, Miller DV, Lu J, Dietz HC, Halushka MK. Histopathologic findings in ascending aortas from individuals with Loeys-Dietz syndrome (LDS). Am J Surg Pathol. 2009;33:194-201.

22. Waters KM, Rooper LM, Guajardo A, Halushka MK. Histopathologic differences partially distinguish syndromic aortic diseases. Cardiovasc Pathol. 2017 30:6-11.

Key Words: aortic aneurysm, aortitis, atherosclerosis, aortic media degeneration, cardiac surgery 
TABLE E1. Clinical findings in patients with or without bicuspid aortic valve

\begin{tabular}{|c|c|c|c|}
\hline Characteristic & $\begin{array}{c}\text { Bicuspid aortic } \\
\text { valve }(\mathrm{N}=77 ; 30.2 \%)\end{array}$ & $\begin{array}{c}\text { Tricuspid aortic } \\
\text { valve }(\mathrm{N}=178 ; 69.8 \%)\end{array}$ & $P$ value \\
\hline Age, y, median (IQR) & $58(49-67)$ & $69(62-75)$ & $<.001$ \\
\hline Male sex, n (\%) & $58(75.3)$ & $131(73.5)$ & .772 \\
\hline BMI, kg/m², median (IQR) & $25(23-29)$ & $26(24-28)$ & .546 \\
\hline Height, $\mathrm{cm}$, mean $\pm \mathrm{SD}$ & $174 \pm 9$ & $170 \pm 10$ & .997 \\
\hline Hypertension (history), n (\%) & $57(74)$ & $154(86.5)$ & .015 \\
\hline Antihypertensive therapy, n (\%) & $56(72.7)$ & $155(87.1)$ & .005 \\
\hline Hypercholesterolemia, n $(\%)^{*}$ & $29(37.6)$ & $81(45.5)$ & .217 \\
\hline Lipid-lowering therapy, n (\%) & $20(25.9)$ & $61(34.2)$ & .191 \\
\hline Diabetes, n (\%) & $8(10.3)$ & $13(7.3)$ & .458 \\
\hline Insulin-dependent diabetes, n (\%) & $7(9.1)$ & $9(5.1)$ & .262 \\
\hline Non-insulin-dependent diabetes, n (\%) & $1(1.2)$ & $4(2.2)$ & .992 \\
\hline Current smoker, n (\%) & $10(12.9)$ & $25(14)$ & .978 \\
\hline Ex-smoker, n (\%) & $19(24.6)$ & $65(36.5)$ & .081 \\
\hline Familial history of CAD, $\mathrm{n}(\%)$ & $12(15.5)$ & $35(19.6)$ & .441 \\
\hline Previous ACS/exertion-induced angina, $\mathrm{n}(\%)$ & $8(10.3)$ & $17(9.6)$ & .836 \\
\hline Previous PTCA or CABG, $n(\%)$ & $5(6.5)$ & $24(13.4)$ & .161 \\
\hline PAOD, n (\%) & $0(0)$ & $1(0.5)$ & .51 \\
\hline Previous stroke/TIA, n (\%) & $2(2.6)$ & $13(7.3)$ & .143 \\
\hline Clinical diagnosis of aortitis, $\mathrm{n}(\%)$ & $1(1.3)$ & $4(2.2)$ & .616 \\
\hline Aortic coarctation, n (\%) & $2(2.5)$ & $1(0.5)$ & .166 \\
\hline Marfan syndrome, n (\%) & $1(1.3)$ & $4(2.2)$ & .616 \\
\hline Turner syndrome, n (\%) & $0(0)$ & $1(0.5)$ & .51 \\
\hline Loeys-Dietz syndrome, n (\%) & $0(0)$ & $1(0.5)$ & .51 \\
\hline Ehlers-Danlos syndrome, $\mathrm{n}(\%)$ & $0(0)$ & $0(0)$ & NA \\
\hline Previous aortic surgery, n (\%) & $4(5.2)$ & $16(8.9)$ & .301 \\
\hline Previous AAS, n (\%) & $0(0)$ & $7(3.9)$ & .078 \\
\hline Known thoracic aortic aneurysm (surgically treated or not), $\mathrm{n}(\%) \dagger$ & $0(0)$ & $13(7.3)$ & .015 \\
\hline Known abdominal aortic aneurysm (surgically treated or not), n (\%) & $0(0)$ & $27(15.1)$ & $<.001$ \\
\hline Familial history of aortic disease & $2(2.5)$ & $13(7.3)$ & .143 \\
\hline GFR, $\mathrm{mL} / \mathrm{min} / 1.73 \mathrm{~m}^{2}$, median (IQR) & $90(75-106)$ & $83(64-101)$ & .379 \\
\hline Systolic blood pressure, mm Hg, median (IQR) & $120(120-130)$ & $120(120-140)$ & .064 \\
\hline Diastolic blood pressure, mm Hg, median (IQR) & $80(70-80)$ & $70(70-80)$ & .613 \\
\hline Maximum ascending aortic diameter, mm, median (IQR) & $49(45-51)$ & $52(48-56) \ddagger$ & $<.001$ \\
\hline
\end{tabular}

$I Q R$, Interquartile range; $B M I$, body mass index; $S D$, standard deviation; $C A D$, coronary artery disease; $A C S$, acute coronary syndrome; PTCA, percutaneous transluminal coronary angioplasty; $C A B G$, coronary artery bypass graft; $P A O D$, peripheral arterial occlusive disease; TIA, transient ischemic attack; $N A$, not applicable; $A A S$, acute aortic syndrome; GFR, glomerular filtration rate. ${ }^{*}$ When the total cholesterol value was $>200$ or when the patient received lipid-lowering therapy. $\dagger$ Aneurysm in a thoracic aortic segment other than ascending. ‡Data available for 176 of 178 patients. 
TABLE E2. Histopathological findings in the study population $(\mathbf{N}=\mathbf{2 5 5})$

\begin{tabular}{|c|c|}
\hline Parameter & Value, $\mathbf{n}(\%)$ \\
\hline \multicolumn{2}{|l|}{ Diagnostic group } \\
\hline Inflammatory-atherosclerosis & $9(3.5)$ \\
\hline Inflammatory-aortitis & $8(3.1)$ \\
\hline Degenerative & $172(67.5)$ \\
\hline Mixed: Degenerative-atherosclerosis & $39(15.2)$ \\
\hline Mixed: Degenerative-aortitis & $18(7.1)$ \\
\hline Mixed: Atherosclerosis-aortitis & $3(1.1)$ \\
\hline Mixed: Degenerative-atherosclerosis-aortitis & $6(2.3)$ \\
\hline \multicolumn{2}{|l|}{ Atherosclerosis grading } \\
\hline Mild & $81(31.7)$ \\
\hline Moderate & $28(10.9)$ \\
\hline Severe & $29(11.3)$ \\
\hline \multicolumn{2}{|l|}{ AHA lesion classification } \\
\hline AHA 1 & $5(1.9)$ \\
\hline AHA 2 & $37(14.5)$ \\
\hline AHA 3 & $62(24.3)$ \\
\hline AHA 4 & $19(7.4)$ \\
\hline AHA 5 & $35(13.7)$ \\
\hline AHA 6 & $9(3.5)$ \\
\hline AHA 7 & $13(5.1)$ \\
\hline Atherosclerosis with excessive inflammation & $1(0.3)$ \\
\hline Inflammatory atherosclerotic aneurysm & $1(0.3)$ \\
\hline Aortitis, total & $35(13.7)$ \\
\hline \multicolumn{2}{|l|}{ Aortitis patterns } \\
\hline Granulomatous/giant cell & $20(7.8)$ \\
\hline Lymphoplasmacytic & $2(0.7)$ \\
\hline Mixed inflammatory & $0(0)$ \\
\hline Suppurative & $0(0)$ \\
\hline Unclassified & $0(0)$ \\
\hline Healing/healed phase & $13(5.1)$ \\
\hline Degenerative & 235 (92.2) \\
\hline Mucoid extracellular matrix accumulation & $244(95.6)$ \\
\hline I-MEMA, total & $201(78.8)$ \\
\hline \multicolumn{2}{|l|}{ I-MEMA grading } \\
\hline Mild & $72(28.2)$ \\
\hline Moderate & $101(39.6)$ \\
\hline Severe & $28(10.9)$ \\
\hline \multicolumn{2}{|l|}{ I-MEMA extent } \\
\hline Focal & 17 (6.6) \\
\hline Multifocal & $167(65.4)$ \\
\hline Diffuse & $17(6.6)$ \\
\hline T-MEMA, total & 234 (91.7) \\
\hline \multicolumn{2}{|l|}{ T-MEMA grading } \\
\hline Mild & $87(34.1)$ \\
\hline Moderate & $108(42.3)$ \\
\hline Severe & $39(15.2)$ \\
\hline T-MEMA extent & $54(21.1)$ \\
\hline \multicolumn{2}{|l|}{ Focal } \\
\hline Multifocal & $174(68.2)$ \\
\hline Diffuse & $7(2.7)$ \\
\hline
\end{tabular}

TABLE E2. Continued

\begin{tabular}{|c|c|}
\hline Parameter & Value, n (\%) \\
\hline LMC, total & $68(26.6)$ \\
\hline \multicolumn{2}{|l|}{ LMC grading } \\
\hline Mild & $16(6.2)$ \\
\hline Moderate & $51(20)$ \\
\hline Severe & $1(0.3)$ \\
\hline \multicolumn{2}{|l|}{ LMC extent } \\
\hline Focal & $40(15.6)$ \\
\hline Multifocal & $26(10.1)$ \\
\hline Diffuse & $2(0.7)$ \\
\hline EFTO, total & $201(78.8)$ \\
\hline \multicolumn{2}{|l|}{ EFTO grading } \\
\hline Mild & $70(27.4)$ \\
\hline Moderate & $101(39.6)$ \\
\hline Severe & 30 (11.7) \\
\hline \multicolumn{2}{|l|}{ EFTO extent } \\
\hline Focal & $21(8.2)$ \\
\hline Multifocal & $163(63.9)$ \\
\hline Diffuse & $17(6.6)$ \\
\hline EFFL, total & 243 (95.2) \\
\hline \multicolumn{2}{|l|}{ EFFL grading } \\
\hline Mild & $90(35.2)$ \\
\hline Moderate & $97(38)$ \\
\hline Severe & $56(21.9)$ \\
\hline \multicolumn{2}{|l|}{ EFFL extent } \\
\hline Focal & $51(20)$ \\
\hline Multifocal & $179(70.1)$ \\
\hline Diffuse & $13(5.1)$ \\
\hline ICI, total & $219(85.8)$ \\
\hline \multicolumn{2}{|l|}{ ICI grading } \\
\hline Mild & $103(40.3)$ \\
\hline Moderate & $100(39.2)$ \\
\hline Severe & $16(6.2)$ \\
\hline \multicolumn{2}{|l|}{ ICI extent } \\
\hline Focal & $15(5.8)$ \\
\hline Multifocal & $167(65.4)$ \\
\hline Diffuse & 37 (14.5) \\
\hline TCI, total & $92(36)$ \\
\hline \multicolumn{2}{|l|}{ TCI grading } \\
\hline Mild & $6(2.3)$ \\
\hline Moderate & $50(19.6)$ \\
\hline Severe & $36(14.1)$ \\
\hline \multicolumn{2}{|l|}{ TCI extent } \\
\hline Focal & $32(12.5)$ \\
\hline Multifocal & $58(22.7)$ \\
\hline Diffuse & $2(0.7)$ \\
\hline $\begin{array}{l}\text { Overall MD grading } \\
\text { Mild }\end{array}$ & $66(25.8)$ \\
\hline Moderate & $130(50.9)$ \\
\hline Severe & $38(14.9)$ \\
\hline Periaortitis, total & 45 (17.6) \\
\hline
\end{tabular}


TABLE E2. Continued

Parameter

Value, n $(\%)$

Periaortitis grading

Mild

$10(3.9)$

Moderate

Severe

$9(3.5)$

AHA, American Heart Association; I-MEMA, intralamellar mucoid extracellular matrix accumulation; T-MEMA, translamellar mucoid extracellular matrix accumulation; $L M C$, laminar medial collapse; EFTO, elastic fiber thinning out; $E F F L$, elastic fiber fragmentation and loss; ICI, intralamellar collagen increase; TCI, translamellar collagen increase. 
TABLE E3. Histopathological findings according to age at presentation in patients with thoracic aortic aneurysm

\begin{tabular}{|c|c|c|c|}
\hline Parameter & $\begin{array}{c}\text { Patients age } \leq 65 \mathrm{y} \\
(\mathrm{N}=118 ; 46.3 \%), \mathrm{n}(\%)\end{array}$ & $\begin{array}{c}\text { Patients age }>65 \mathrm{y} \\
(\mathrm{N}=137 ; 53.7 \%), \mathrm{n}(\%)\end{array}$ & $P$ value \\
\hline \multicolumn{4}{|l|}{ Diagnostic group } \\
\hline Inflammatory-atherosclerosis & $3(2.5)$ & $6(4.3)$ & .650 \\
\hline Inflammatory-aortitis & $1(0.8)$ & $7(5.1)$ & .112 \\
\hline Degenerative & $99(83.8)$ & $73(53.2)$ & $<.001$ \\
\hline Mixed: Degenerative-atherosclerosis & $10(8.4)$ & $29(21.1)$ & .008 \\
\hline Mixed: Degenerative-aortitis & $5(4.2)$ & $13(9.4)$ & .165 \\
\hline Mixed: Atherosclerosis-aortitis & $0(0)$ & $3(2.1)$ & .3 \\
\hline Mixed: Degenerative-atherosclerosis-aortitis & $0(0)$ & $6(4.3)$ & .059 \\
\hline \multicolumn{4}{|l|}{ Atherosclerosis grading } \\
\hline Mild & $41(34.7)$ & $40(29.1)$ & .415 \\
\hline Moderate & $8(6.7)$ & $20(14.5)$ & .073 \\
\hline Severe & $5(4.2)$ & $24(17.5)$ & .001 \\
\hline \multicolumn{4}{|l|}{ AHA lesion classification } \\
\hline AHA 1 & $3(2.5)$ & $2(1.4)$ & .866 \\
\hline AHA 2 & $17(14.4)$ & $30(21.8)$ & .168 \\
\hline AHA 3 & $32(27.1)$ & $30(21.8)$ & .410 \\
\hline AHA 4 & $9(7.6)$ & $10(7.2)$ & .920 \\
\hline AHA 5 & $9(7.6)$ & $26(18.9)$ & .014 \\
\hline AHA 6 & $3(2.5)$ & $6(4.3)$ & 651 \\
\hline AHA 7 & $1(0.8)$ & $12(8.7)$ & .009 \\
\hline Atherosclerosis with excessive inflammation & $0(0)$ & $1(0.7)$ & .352 \\
\hline Inflammatory atherosclerotic aneurysm & $0(0)$ & $1(0.7)$ & .352 \\
\hline Aortitis, total & $6(5.1)$ & $29(21.1)$ & $<.001$ \\
\hline \multicolumn{4}{|l|}{ Aortitis patterns } \\
\hline Granulomatous/giant cell & $4(3.3)$ & $16(11.6)$ & .026 \\
\hline Lymphoplasmacytic & $0(0)$ & $2(1.4)$ & .544 \\
\hline Mixed inflammatory & $0(0)$ & $0(0)$ & 1 \\
\hline Suppurative & $0(0)$ & $0(0)$ & 1 \\
\hline Unclassified & $0(0)$ & $0(0)$ & 1 \\
\hline Healing/healed phase & $2(1.6)$ & $11(8)$ & .044 \\
\hline Degenerative & $114(96.6)$ & $121(88.3)$ & .026 \\
\hline Mucoid extracellular matrix accumulation & $115(97.4)$ & $129(94.1)$ & .325 \\
\hline I-MEMA, total & $102(86.4)$ & $99(72.2)$ & $<.001$ \\
\hline \multicolumn{4}{|l|}{ I-MEMA grading } \\
\hline Mild & $41(34.7)$ & $31(22.6)$ & .045 \\
\hline Moderate & $46(38.9)$ & $55(40.1)$ & .951 \\
\hline Severe & $15(12.7)$ & $13(9.4)$ & .535 \\
\hline \multicolumn{4}{|l|}{ I-MEMA extent } \\
\hline Focal & $11(9.3)$ & $6(4.3)$ & .184 \\
\hline Multifocal & $83(70.3)$ & $84(61.3)$ & .167 \\
\hline Diffuse & $8(6.7)$ & $9(6.5)$ & .946 \\
\hline T-MEMA, total & $108(91.5)$ & $126(91.9)$ & .897 \\
\hline \multicolumn{4}{|l|}{ T-MEMA grading } \\
\hline Mild & $43(36.4)$ & $44(32.1)$ & .552 \\
\hline Moderate & 49 (41.5) & $59(43)$ & .903 \\
\hline Severe & $16(13.5)$ & $23(16.7)$ & .589 \\
\hline \multicolumn{4}{|l|}{ T-MEMA extent } \\
\hline Focal & $26(22)$ & $28(20.4)$ & .875 \\
\hline Multifocal & $79(66.9)$ & $95(69.3)$ & .783 \\
\hline Diffuse & $3(2.5)$ & $3(2.1)$ & .853 \\
\hline
\end{tabular}


TABLE E3. Continued

\begin{tabular}{|c|c|c|c|}
\hline Parameter & $\begin{array}{c}\text { Patients age } \leq 65 \mathrm{y} \\
(\mathrm{N}=118 ; \mathbf{4 6 . 3} \%), \mathrm{n}(\%)\end{array}$ & $\begin{array}{c}\text { Patients age }>65 \mathrm{y} \\
(\mathrm{N}=137 ; 53.7 \%), \mathrm{n}(\%)\end{array}$ & $P$ value \\
\hline LMC, total & $31(26.2)$ & $37(27)$ & .894 \\
\hline \multicolumn{4}{|l|}{ LMC grading } \\
\hline Mild & $10(8.4)$ & $6(4.3)$ & .277 \\
\hline Moderate & $20(16.9)$ & $31(22.6)$ & .330 \\
\hline Severe & $1(0.8)$ & $0(0)$ & .940 \\
\hline \multicolumn{4}{|l|}{ LMC extent } \\
\hline Focal & $19(16.1)$ & $21(15.3)$ & .865 \\
\hline Multifocal & $10(8.4)$ & 16 (11.6) & .525 \\
\hline Diffuse & $2(1.6)$ & $0(0)$ & .413 \\
\hline EFTO, total & $102(86.4)$ & $99(72.2)$ & .009 \\
\hline \multicolumn{4}{|l|}{ EFTO grading } \\
\hline Mild & $42(35.5)$ & $28(20.4)$ & .01 \\
\hline Moderate & $45(38.1)$ & $56(40.8)$ & .750 \\
\hline Severe & 15 (12.7) & $15(10.9)$ & .809 \\
\hline \multicolumn{4}{|l|}{ EFTO extent } \\
\hline Focal & $12(10.1)$ & $9(6.5)$ & .415 \\
\hline Multifocal & $82(69.4)$ & $81(59.1)$ & .112 \\
\hline Diffuse & $8(6.7)$ & $9(6.5)$ & .946 \\
\hline EFFL, total & $109(92.3)$ & $134(97.8)$ & .08 \\
\hline \multicolumn{4}{|l|}{ EFFL grading } \\
\hline Mild & $46(38.9)$ & $44(32.1)$ & .311 \\
\hline Moderate & $46(38.9)$ & $51(37.2)$ & .873 \\
\hline Severe & $17(14.4)$ & $39(28.4)$ & .01 \\
\hline \multicolumn{4}{|l|}{ EFFL extent } \\
\hline Focal & $26(22)$ & $25(18.2)$ & .550 \\
\hline Multifocal & $79(66.9)$ & $100(72.9)$ & .360 \\
\hline Diffuse & $4(3.3)$ & $9(6.5)$ & .386 \\
\hline ICI, total & 107 (90.6) & $112(81.7)$ & .06 \\
\hline \multicolumn{4}{|l|}{ ICI grading } \\
\hline Mild & $59(50)$ & $44(32.1)$ & .005 \\
\hline Moderate & $43(36.4)$ & 57 (41.6) & .475 \\
\hline Severe & $5(4.2)$ & $11(8)$ & .324 \\
\hline \multicolumn{4}{|l|}{ ICI extent } \\
\hline Focal & $8(6.7)$ & $7(5.1)$ & .765 \\
\hline Multifocal & $80(67.7)$ & 87 (63.5) & .557 \\
\hline Diffuse & $19(16.1)$ & $18(13.1)$ & .623 \\
\hline TCI, total & $28(23.7)$ & $64(46.7)$ & $<.001$ \\
\hline \multicolumn{4}{|l|}{ TCI grading } \\
\hline Mild & $3(2.5)$ & $3(2.1)$ & .853 \\
\hline Moderate & $17(14.4)$ & $33(24.1)$ & .07 \\
\hline Severe & $8(6.7)$ & $28(20.4)$ & .003 \\
\hline \multicolumn{4}{|l|}{ TCI extent } \\
\hline Focal & $12(10.1)$ & $20(14.5)$ & .381 \\
\hline Multifocal & $15(12.7)$ & $43(31.3)$ & $<.001$ \\
\hline Diffuse & $1(0.8)$ & $1(0.7)$ & .915 \\
\hline \multicolumn{4}{|l|}{ Overall MD grading } \\
\hline Mild & $36(30.5)$ & $30(21.8)$ & .155 \\
\hline Moderate & $57(48.3)$ & $73(53.2)$ & .504 \\
\hline Severe & $21(17.7)$ & $17(12.4)$ & .303 \\
\hline
\end{tabular}


TABLE E3. Continued

\begin{tabular}{|c|c|c|c|}
\hline Parameter & $\begin{array}{c}\text { Patients age } \leq 65 \text { y } \\
(\mathrm{N}=118 ; 46.3 \%), \mathbf{n}(\%)\end{array}$ & $\begin{array}{c}\text { Patients age }>65 \mathrm{y} \\
(\mathrm{N}=137 ; 53.7 \%), \mathbf{n}(\%)\end{array}$ & $P$ value \\
\hline Periaortitis, total & $10(8.4)$ & $35(25.5)$ & $<.001$ \\
\hline \multicolumn{4}{|l|}{ Periaortitis grading } \\
\hline Mild & $2(1.6)$ & $8(5.8)$ & .168 \\
\hline Moderate & $6(5.1)$ & $20(14.5)$ & .02 \\
\hline Severe & $2(1.6)$ & $7(5.1)$ & .257 \\
\hline
\end{tabular}

